\title{
Pengaruh Penggunaan Media Sosial dan Efektivitas Akun Instagram @bogoreatery terhadap Pemenuhan Kebutuhan Informasi Konsumen Wisata Kuliner di Bogor
}

\author{
Fadia Syah Putranto1, Rezi Erdiansyah ${ }^{2 *}$ \\ ${ }^{1}$ Fakultas Ilmu Komunikasi, Universitas Tarumanagara, Jakarta \\ Email:fadiasyah5@gmail.com \\ ${ }^{2}$ Fakultas Ilmu Komunikasi, Universitas Tarumanagara, Jakarta* \\ Email: rezie@fikom.untar.ac.id
}

Masuk tanggal: 15-12-2021, revisi tanggal: 06-01-2022, diterima untuk diterbitkan tanggal: 16-01-2022

\begin{abstract}
Instagramaccount @bogoeatery is an account based on information content about culinary tourism in Bogor. The account makes it easier for Instagram social media users to find culinary tourism information through various content provided to other users. This study aims to determine the effect of using social media and the effectiveness of the @bogoreeatery Instagram account on meeting the information needs of culinary tourism consumers in Bogor. The author uses the theory of the use of social media, the theory of effectiveness and the fulfillment of information needs as research concepts. The research method used is an explanatory survey of 100 respondents as a sample with a questionnaire as the author's instrument. The data obtained were analyzed using validity test, reliability test, normality test, multiple linear regression analysis, coefficient of determination, $f$ test and $t$ test. From this research, the results of the multiple linear regression equation are $Y=(-0.089)+0.293+$ 0.795 value (sig) 0.000. This means that every 1 unit increase in the use of social media will increase the fulfillment of information needs by 0.293. Likewise, every increase in the effectiveness of an Instagram account by 1 unit will increase the fulfillment of information needs by 0.795 , which means that the use of social media and the effectiveness of the Instagram account @ bogoeatery has a significant influence on meeting the information needs of culinary tourism consumers in Bogor.
\end{abstract}

Keywords: effectiveness, fulfilling information needs, Instagram, use of social media

\begin{abstract}
Abstrak
Akun Instagram @bogoreatery merupakan salah satu akun yang berbasis konten informasi seputar wisata kuliner di Bogor. Akun tersebut memudahkan pengguna media sosial Instagram dalam mencari informasi wisata kuliner melalui berbagai konten yang diberikan kepada pengguna lainnya. Penelitian bertujuan untuk mengetahui pengaruh penggunaan media sosial dan efektivitas akun Instagram @bogoreatery terhadap pemenuhan kebutuhan informasi konsumen wisata kuliner di Bogor. Penulis menggunakan teori serta konsep penelitian yaitu penggunaan media sosial, teori efektivitas komunikasi dan pemenuhan kebutuhan informasi. Metode penelitian yang dilakukan yaitu eksplanatif berdasarkan survei terhadap 100 responden sebagai sampel dengan kuisioner sebagai instrumen penulis. Data yang diperoleh dianalisis dengan menggunakan uji reabilitas, uji validitas, uji normalitas, analisis regresi linear berganda, koefesien determinasi, uji f dan uji t. Dari penelitian ini diperoleh hasil persamaan regresi linier berganda yaitu $Y=(-0,089)+0,293+0,795$ nilai $(\mathrm{sig}) 0.000$. Hal ini diartikan setiap peningkatan sebesar 1 satuan pada penggunaan media sosial akan meningkatkan pemenuhan kebutuhan informasi sebesar 0,293. Begitu pula dengan setiap peningkatan efektivitas akun Instagram sebesar 1 satuan akan meningkatkan pemenuhan kebutuhan informasi sebesar 0,795, yang berarti penggunaan media sosial dan efektivitas akun
\end{abstract}


Instagram @bogoreatery memiliki pengaruh positif yang signifikan terhadap pemenuhan kebutuhan informasi konsumen wisata kuliner di Bogor.

Kata Kunci: efektivitas, Instagram, pemenuhan kebutuhan informasi, penggunaan media sosial

\section{Pendahuluan}

Seiring perkembangan zaman, teknologi mengalami kemajuan yang begitu pesat, sehingga dapat meringankan sekaligus membantu berbagai kegiatan manusia khususnya dalam berkomunikasi, mencari informasi, hingga mendapatkan berbagai informasi yang dibutuhkan di media sosial. Hal tersebut bisa dilakukan melalui platform media sosial Instagram. Berdasarkan survei Jakpat, Instragam menduduki posisi ke-3 di Indonesia sebagai platfrom media sosial yang paling banyak digunakan dengan nilai persentase pengguna aktif sebesar 77\% (Annur, 2021).

Instagram kini tidak hanya digunakan untuk kepentingan pribadi, banyak pengguna yang memanfaatkan untuk membuat akun komunitas, perusahaan, hingga media untuk menyebarkann suatu informasi. @bogoreatery merupakan salah satu akun Instagram yang banyak diikuti oleh pengguna sosial media Instagram lainnya dalam pemenuhan kebutuhan informasi. Melihat saat ini manusia memiliki kebutuhan tinggi akan sebuah informasi, dengan begitu akun Instagram bisa menjadi wadah untuk memenuhi ragam jenis kebutuhan informasi khususnya terkait berbagai destinasi wisata kuliner di Bogor dari akun Instagram @bogoreatery.

Sumber media yang lebih baik dikonsumsi untuk memenuhi suatu kebutuhan telah menjadi upaya yang dilakukan para pengguna media dalam memilih sumber. Belkin menjelaskan bahwa kebutuhan informasi akan diperoleh saat adanya ketiadaan akan suatu keadaan pada hal tertentu yang telah diketahui manusia, selain itu manusia memiliki keinginan untuk mengalahkan kekurangan tersebut (Rumyeni, 2015). Meskipun di tengah pandemi Covid-19, Bogor tetap menjadi salah satu pilihan favorit bagi wisatawan asing maupun lokal khususnya bagi warga DKI Jakarta bahkan sejak zaman Belanda (Arbi, 2021). Salah satu hal yang membuat wisatawan tertarik ke Bogor ialah melimpahnya destinasi wisata kuliner. Berdasarkan penjelasan latar belakang tersebut peneliti akan membuktikan apakah terdapat pengaruh penggunaan media sosial dan efektivitas akun Instagram @bogoreatry terhadap pemenuhan kebutuhan informasi konsumen wisata kuliner di bogor. Serta berapa besar pengaruh penggunaan media sosial dan efektivitas akun instagram @bogoreatery terhadap pemenuhan kebutuhan informas konsumen wisata kuliner di bogor. Berikut adalah hipotesis yang peneliti rumuskan dalam penelitian ini:

H1: Penggunaan media sosial berpengaruh positif terhadap pemenuhan kebutuhan informasi konsumen wisata kuliner di Bogor.

H2: Efektivitas akun Instagram @ bogoreatery berpengaruh positif terhadap pemenuhan kebutuhan informasi konsumen wisata kuliner di Bogor.

H3: Penggunaan media sosial dan efektivitas akun Instagram @bogoreatery berpengaruh positif terhadap pemenuhan kebutuhan informasi konsumen wisata kuliner di Bogor.

\section{Metode Penelitian}

Dalam melakukan penelitian ini pendekatan yang dipilih oleh penulis adalah kuantitatif. Penelitian kuantitatif memiliki pengertian yaitu suatu kegiatan pengolahan, 
Fadia Syah Putranto, Rezi Erdiansyah: Pengaruh Penggunaan Media Sosial dan Efektivitas Akun Instagram@bogoreatery terhadap Pemenuhan Kebutuhan Informasi Konsumen Wisata Kuliner di Bogor

pengumpulan, analisis dan penyajian data berdasarkan banyaknya atau jumlah yang dilakukan secara objektif untuk menguji suatu hipotesis dalam mengembangkan prinsip-prinsip umum atau untuk memecahkan suatu persoalan (Duli, 2019). Peneliti menggunakan metode survei untuk melakukan penelitannya. Metode survei sendiri merupakan penelitian dengan menggunakan jawaban orang-orang sebagai data penelitian (Suryadi, 2019). Untuk memperoleh data tersebut dilakukan dengan menggunakan serangkaian pertanyaan yang dirancang dengan cara tertentu atau disebut angket (questionnaire) sebagai instrumen penelitian.

Penarikan sampel digunakan dengan teknik purposive sampling. Purposive sampling merupakan cara dalam penarikan sampel dengan menentukan kriteria tertentu yang ditetapkan oleh peneliti, dengan begitu seluruh populasi harus sesuai dengan kriteria yang ditetapkan, sehinggap dapat diambil sebagai sampel penelitian. Populasi sendiri merupakan keseluruhan objek yang digunakan dalam sebuah penelitian. Populasi dipilih karena mempunyai karakter dan ciri tertentu sebagai sumber data untuk diambil kesimpulannya, sedangkan sampel merupakan sebagian anggota populasi untuk menjadi perwakilan populasinya. Sampel dilakukan dengan menetapkan kriteria orang yang memiliki informasi tentang sesuatu adalah mereka yang pernah terlibat atau sedang berada di lingkungan situasi itu. Dalam penelitian ini populasinya adalah wisatawan Bogor sebanyak dua juta orang menurut Dinas Pariwisata dan Kebudayaan Pemerintah Kota Bogor tahun 2020 dalam (Ali, 2021). Berdasarkan penghitungan sampel menggunakan rumus Slovin, jumlah sampel minimal yang diperoleh penulis adalah 100 sampel berdasarkan hasil pembulatan dari angka yang diperoleh yaitu 99,99.

Data yang sudah dikumpulkan selanjutnya diolah dan dianalisis dengan menggunakan uji reabilitas, uji validitas, uji normalitas, uji koefesien determinasi, analisis regresi linear berganda, uji siginifikansi stimultan (uji f), dan uji siginifikansi parameter individual (uji t).

\section{Hasil Temuan dan Diskusi}

@bogoreatery merupakan akun Instagram berbasis konten informasi foodictionary in Bogor dengan disertai gambar dan video seputar informasi wisata kuliner di Bogor (Gambar.1). Akun tersebut memiliki ciri tersendiri yaitu memberikan informasi dalam bentuk konten Instagram khusus mengenai destinasi wisata kuliner di Bogor, @bogoreatery juga sangat spesifik menyediakan informasi yang up to date setiap harinya untuk para pecinta makanan mengenai tempat atau daerah yang menyediakan berbagai macam kuliner di Bogor. Melalui akun Instagram tersebut, setiap pengguna aktif media sosial Instagram yang cinta atau suka terhadap wisata kuliner di Bogor dapat mencari informasi spesifik mengenai destinasi kuliner yang terdapat di Bogor dengan mudah. Akun Instagram @bogoreatery telah diikuti oleh lebih dari 182.000 followers dan memiliki postingan foto dan video sebanyak 1.809 per tanggal 30 November 2021 (Gambar.2). 
Gambar 1. Profil Instagram @bogoreatery

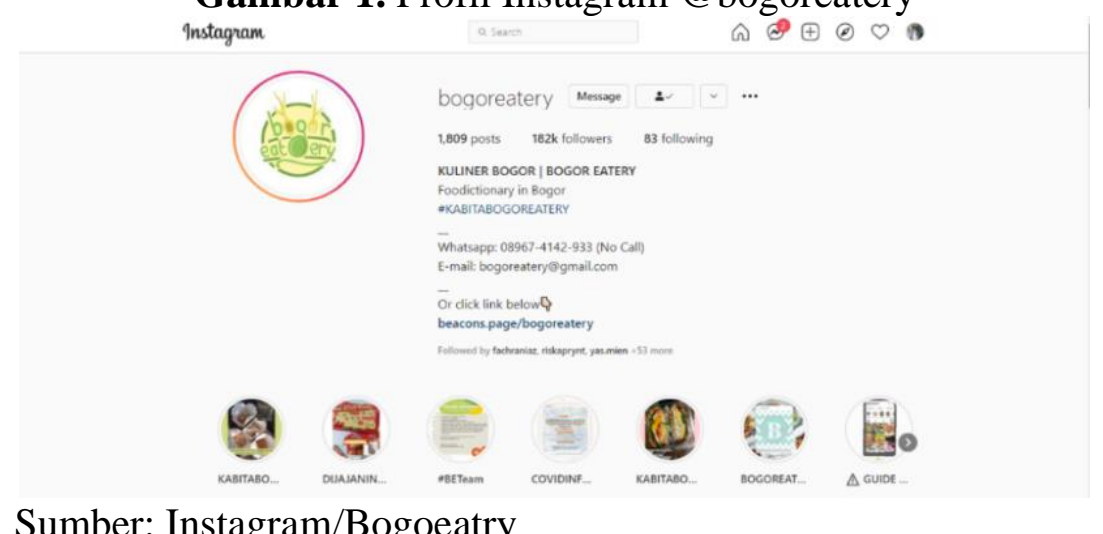

Sumber: Instagram/Bogoeatry

Gambar 2. Feeds Instagram @ bogoreater
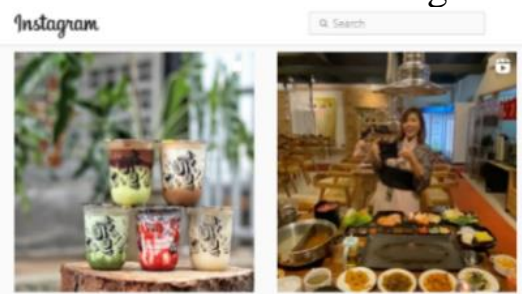

( $\odot \oplus \odot \circ$
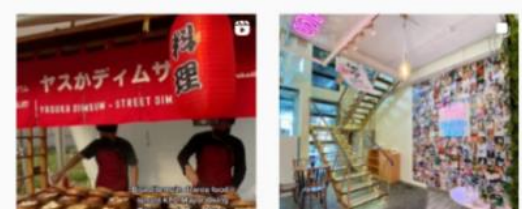

Sumber: Instagram/Bogoeatery

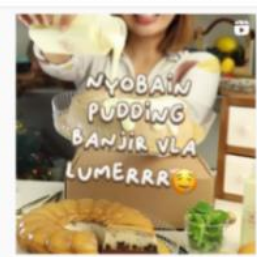

Dalam melakukan penelitian, penulis mendapatkan data primer dengan cara menyebarkan angket atau kuisioner kepada sampel yang telah memenuhi kriteria yaitu 100 responden yang ditetapkan sebagai pengguna aktif media sosial Instagram, mengetahui akun Instagram @ bogoreatery dan konsumen wisata kuliner di Bogor. Hasil jawaban responden diolah menggunakan SPSS Ver. 25 untuk mengetahui validitas, reliabilitas, normalitas, analisis regresi linear berganda, koefesien determinasi, uji f, dan uji t.

Tabel 1. Uji Normalitas

One-Sample Kolmogorov-Smirnov Test

\begin{tabular}{llr}
\hline & & \multicolumn{1}{c}{$\begin{array}{c}\text { Unstandardized } \\
\text { Residual }\end{array}$} \\
\hline$N$ & & 100 \\
\hline Normal Parameters ${ }^{a, b}$ & Mean & $0.00 \mathrm{E}+00$ \\
\cline { 2 - 3 } & Std. Deviation & 2.8011756 \\
\hline Most Extreme Differences & Absolute & 0.118 \\
\cline { 2 - 3 } & Positive & 0.118 \\
\cline { 2 - 3 } & Negative & -0.112 \\
\hline Kolmogorov-Smirnov $Z$ & & 1.183 \\
\hline Asymp. Sig. (2-tailed) & & 0.122 \\
\hline a. Test distribution is Normal. & & \\
\hline b. Calculated from data. & & \\
\hline Sumber: Pengolahan Data & & \\
\hline
\end{tabular}

Sumber: Pengolahan Data Oleh Peneliti 
Fadia Syah Putranto, Rezi Erdiansyah: Pengaruh Penggunaan Media Sosial dan Efektivitas Akun Instagram@bogoreatery terhadap Pemenuhan Kebutuhan Informasi Konsumen Wisata Kuliner di Bogor

Tabel 2. Uji F

\begin{tabular}{|c|c|c|c|c|c|c|}
\hline \multicolumn{7}{|c|}{ ANOVA $^{a}$} \\
\hline Model & & $\begin{array}{l}\text { Sum of } \\
\text { Squares }\end{array}$ & $d f$ & $\begin{array}{l}\text { Mean } \\
\text { Square }\end{array}$ & $F$ & Sig. \\
\hline \multirow[t]{3}{*}{1} & Regression & 2212.178 & 2 & 1106.089 & 138.117 & $.000^{\mathrm{b}}$ \\
\hline & Residual & 776.812 & 97 & 8.008 & & \\
\hline & Total & 2988.990 & 99 & & & \\
\hline
\end{tabular}

a. Dependent Variable: Kebutuhan Informasi

b. Predictors: (Constant), Efektivitas Instagram, Penggunaan Media Sosial

Sumber: Pengolahan Data Oleh Peneliti

Tabel 3. Uji T

\begin{tabular}{|c|c|c|c|c|c|c|}
\hline \multirow{3}{*}{ Model } & \multicolumn{6}{|c|}{ Coefficientsa } \\
\hline & & \multicolumn{2}{|c|}{$\begin{array}{c}\text { Unstandardized } \\
\text { Coefficients }\end{array}$} & \multirow{2}{*}{$\begin{array}{c}\text { Standardized } \\
\text { Coefficients } \\
\text { Beta }\end{array}$} & \multirow[t]{2}{*}{$t$} & \multirow[t]{2}{*}{ Sig. } \\
\hline & & B & $\begin{array}{l}\text { Std. } \\
\text { Error }\end{array}$ & & & \\
\hline \multirow[t]{3}{*}{1} & (Constant) & -0.089 & 2.311 & & -0.038 & 0.969 \\
\hline & $\begin{array}{l}\text { Penggunaan } \\
\text { Media Sosial }\end{array}$ & 0.293 & 0.055 & 0.483 & 5.315 & 0.000 \\
\hline & $\begin{array}{l}\text { Efektivitas } \\
\text { Instagram }\end{array}$ & 0.795 & 0.173 & 0.418 & 4.591 & 0.000 \\
\hline
\end{tabular}

a. Dependent Variable: Kebutuhan Informasi

Sumber: Pengolahan Data Oleh Peneliti

Tabel 4. Uji Koefesien Determinasi

\begin{tabular}{lrrrr}
\hline \multicolumn{5}{c}{ Model Summary $^{b}$} \\
\hline Model & $R$ & $R$ Square & $\begin{array}{c}\text { Adjusted } R \\
\text { Square }\end{array}$ & $\begin{array}{l}\text { Std. Error of } \\
\text { the Estimate }\end{array}$ \\
\hline 1 & & & & \\
\hline
\end{tabular}

a. Predictors: (Constant), Efektivitas Instagram, Penggunaan Media Sosial

b. Dependent Variable: Kebutuhan Informasi

Sumber: Pengolahan Data Oleh Peneliti

Berdasarkan Tabel 4, nilai $R$ Square yang akan dilihat untuk melihat seberapa besar pengaruhnya. Pada data ditunjukkan nilai $R$ Square sebesar 0,740 yang dapat diinterpretasikan sebersar $74 \%$, sehingga seluruh variabel bebas (X1 dan X2) mempengaruhi variabel terikat (Y). Sementara sisanya terdapat variabel lain yang tidak penulis teliti dengan presentase sebesar $26 \%$.

Tabel 5. Regresi Linear Berganda

$\begin{array}{cc}\text { Unstandardized } & \text { Standardized } \\ \text { Coefficients } & \text { Coefficients }\end{array}$

Sig.

B Std. Error Beta 


\begin{tabular}{llcccc}
\hline 1 (Constant) & -0.089 & 2.311 & & -0.038 & 0.969 \\
& & & & & \\
\hline $\begin{array}{l}\text { Penggunaan } \\
\text { Media Sosial }\end{array}$ & 0.293 & 0.055 & 0.483 & 5.315 & 0.000 \\
& & & & & \\
\hline $\begin{array}{l}\text { Efektivitas } \\
\text { Instagram }\end{array}$ & 0.795 & 0.173 & 0.418 & 4.591 & 0.000 \\
\hline a. Dependent Variable: Kebutuhan Informasi & & & \\
\hline
\end{tabular}

Sumber: Pengolahan Data Oleh Peneliti

Berdasarkan data dalam tabel 5, nilai penggunaan media sosial (X1) sebesar 0,293 dan nilai efektivitas akun Instagram (X2) sebesar 0,795. Nilai constant berarti nilai $\alpha$ yang bernilai $-0,089$. Dari hasil tersebut terdapat persamaan regresi linier berganda yaitu $Y=(-0,089)+0,293+0,795$. Sehingga dapat dijelaskan bahwa setiap adanya peningkatan sebesar 1 satuan pada penggunaan media sosial akan meningkatkan pemenuhan kebutuhan informasi sebesar 0,293. Begitu pula dengan setiap peningkatan keefektivitas akun Instagram sebesar 1 satuan akan meningkatkan pemenuhan kebutuhan informasi sebsar 0,795.

Pada uji regresi linier berganda diketahui hipotesis tiga (H3) diterima, yaitu variabel penggunaan media sosial (X1) dan variabel efektivitas akun Instagram (X2) memiliki pengaruh yang signifikan terhadap variabel pemenuhan kebutuhan informasi (Y). Serta pada uji koefesien determinasi nilai $R$ Square sebesar 0,740 atau dapat diinterpretasikan sebagai 74\%. Berarti seluruh variabel bebas (penggunaan media sosial dan efektivitas akun Instagram) mempengaruhi secara signifikan variabel terikat (pemenuhan kebutuhan informasi) sebesar 74\%.

Dalam teori uses and gratifications yang memiliki salah satu asumsi dasar menurut Katz, Bulmer dan Gurevitch dalam (Suherman, 2020) dikatakan bahwa orang yang aktif dengan menggunakan media berinisiatif atas keterlibatan pemuasan kebutuhan dalam memilih sebuah media, salah satunya adalah pemenuhan kebutuhan informasi. Pada penelitian ini, berdasarkan 100 responden yang ditetapkan sebagai sampel penelitian penggunaan media sosial dan efektivitas akun Instagram @ bogoreatery memiliki pengaruh signifikan sebesar 74\% sebagai sarana pemenuhan kebutuhan informasi yang dianggap menjadi sumber terbaik di Instagram menurut responden yang telah mengisi kuisioner.

\section{Simpulan}

Berdasarkan hasil penelitian "Pengaruh Penggunaan Media Sosial dan Efektivitas Akun Instagram @bogoreatery Terhadap Pemenuhan Kebutuhan Informasi Konsumen Wisata Kuliner di Bogor" terdapat kesimpulan sebagai berikut:

a. Merujuk pada hasil uji $t$ atau uji parsial dari masing-masing variabel, terdapat nilai $\mathrm{T}$ hitung variabel penggunaan media sosial sebesar 5,315 dan nilai $\mathrm{T}$ hitung efevtivitas akun Instagram sebesar 4,591. Kedua variabel bebas memiliki nilai $\mathrm{T}$ hitung lebih besar dari $\mathrm{T}$ tabel dengan nilai 1,6607. Dengan hasil tersebut artinya penggunaan media sosial (X1) dan efektivtas akun Instagram @bogoreatery (X2) berpengaruh positif secara signifikan terhadap pemenuhan kebutuhan infromasi konsumen wisata kuliner di Bogor (Y).

b. Berdasarkan hasil olahan data koefesien determinasai, nilai $R$ Square sebesar 0,740 atau dapat diinterpretasikan sebagai $74 \%$. Berarti seluruh variabel bebas 
Fadia Syah Putranto, Rezi Erdiansyah: Pengaruh Penggunaan Media Sosial dan Efektivitas Akun Instagram@bogoreatery terhadap Pemenuhan Kebutuhan Informasi Konsumen Wisata Kuliner di Bogor

yaitu penggunaan media sosial dan efektivitas akun Instagram @bogoreatery mempengaruhi variabel terikat yakni pemenuhan kebutuhan informasi sebesar $74 \%$. Kemudian sisa perhitungan sebesar $26 \%$ dipengaruhi oleh variabel berbeda yang tidak penulis teliti. Dengan hasil tersebut dapat disimpulkan bahwa penggunaan media sosial (X1) dan efektivitas akun Instagram (X2) mempengaruhi sebesar 74\% terhadap pemenuhan kebutuhan informasi (Y).

\section{Ucapan Terima Kasih}

Peneliti ingin mengucapkan terima kasih kepada Fakultas Ilmu Komunikasi Universitas Tarumanagara, narasumber, serta semua pihak yang turut membantu peneliti sehingga penelitian ini dapat diselesaikan.

\section{Daftar Pustaka}

Ali, M. (2021, 09 25). Pemkot Bogor Harapkan Peningkatan Wisatawan pada Akhir Pekan. Retrieved from liputan6.com: https://www.liputan6.com/news/read/4667545/pemkot-bogor-harapkanpeningkatan-wisatawan-pada-akhir-pekan

Annur, C. M. (2021, September 01). Masyarakat Indonesia Paling Banyak Akses YouTubepada Semester I-2021. Retrieved from https://databoks.katadata.co.id: https://databoks.katadata.co.id/datapublish/2021/09/05/masyarakat-indonesiapaling-banyak-akses-youtubepada-semester-i-2021

Arbi, I. A. (2021, 08 31). Kembali Dipadati Wisatawan, Bogor Sudah Menjadi "Pelarian" Warga Jakarta Sejak Era Belanda. Retrieved from megapolitan.kompas.com:

https://megapolitan.kompas.com/read/2021/08/31/11594351/kembalidipadati-wisatawan-bogor-sudah-jadi-pelarian-warga-jakarta-sejak?page=all

Duli, N. (2019). Metodologi Penelitian Kuantitatif: Beberapa Konsep Dasar Untuk Penulisan Skripsi \& Analisis Data Dengan SPSS. Yogyakarta: Deepublish.

Rumyeni, B. (2015). Pengaruh Media Sosial Twitter @Lowkerpku terhadap Pemenuhan Kebutuhan Informasi Lowongan Kerja Bagi Followers. Jurnal Online Mahasiswa Fakultas Ilmu Sosial dan Ilmu Politik Universitas Riau, Volume 2 Nomor 2.

Suherman, A. (2020). Buku Ajar Teori-teori Komunikasi. Yogyakarta: Deepublish.

Suryadi, E. (2019). Metode Penelitian Komunikasi Dengan Pendekatan Kuantitatif. Bandung: PT Remaja Rosdakarya. 